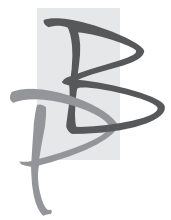

\title{
Media, Community Building, and Refugee Resettlement Policies: The Impact of Canada's Welcoming Culture and Media Coverage on the Settlement Outcomes of Resettled Syrian Refugees
}

\begin{abstract}
This paper argues that positive online media coverage of Syrian refugees arriving in Canada, and the welcoming culture of Canadian society, have both influenced positive settlement and integration outcomes for Syrian refugees. It also provides a better understanding of Canada's response to the Syrian refugee crisis and shows how the process of resettlement becomes stronger when local community members and citizens are involved. These arguments are demonstrated firstly by analyzing the relationship between welcoming cultures, positive media coverage, and the perception of refugees. Secondly, the role of media coverage in influencing welcoming cultures in $\mathrm{Ca}$ nada, as well as its role in encouraging community members and ordinary citizens to be involved in national humanitarian projects,
\end{abstract}

\footnotetext{
Mounir Nasri is a social entrepreneur and advisor in the field of community development. He is currently working with Toronto's Local Immigration Partnership, where he leads and coordinates crosssectoral innovative programs and collaborations to build and sustain welcoming and inclusive communities for new Canadians. Mounir holds a Master of Management in Innovation and Entrepreneurship (MMIE) from Smith School of Business at Queen's University, where he also earned a Bachelor of Arts (BA) with distinction in Global Development Studies after studying Computer Science at Haigazian University in Lebanon.
} 
is described. Finally, information related to Canada's welcoming culture and positive media coverage are discussed relative to settlement outcomes, which portrays the strong influence of storytelling and inclusive communities on the success of new immigrants as they rebuild their lives in a new country. The various refugee resettlement programs in Canada are also outlined. The Canadian response to the Syrian refugee crisis has demonstrated to the world a different approach to civic engagement and humanitarian work. This national humanitarian response may be perceived as a major successful project. Nevertheless, it also leaves us with many unanswered questions around the topic, and most importantly, questions about the relationship between politics and power, citizenship, culture, online media and public opinions.

Key words: Community building, migration, public opinion, storytelling, inclusion, citizenship.

\section{Introduction}

In November 2015, when the new Canadian federal government led by Justin Trudeau and the Liberal Party came into power, a commitment was made to help resettle 25,000 Syrian refugees before the end of February 2016 1,2. With that announcement, the state began to lead various initiatives in order to help refugees settle, providing housing, employment, education and other essential needs. Citizens and members of civil society also played a big part in this national project, as they took on different roles to help empower the

A. M. B. McMurdo, Causes and Consequences of Canada's Resettlement of Syrian Refugees, "Forced Migration Review", 52: 2016, pp. 82-84.

2 S. Levitz, A Timeline of Canada's Policies and Decisions during the Syrian Refugee Crisis, “The Canadian Press", March 31 2016: https://toronto.citynews.ca/2016/03/31/a-timeline-of-canadas-policies-and-decisions-during-the-syrian-refugee-crisis/, [Accessed 16 May 2017]. 
newcomers ${ }^{3}$. The response did not stop there. Canadian media channels, organizations and governmental institutions also took this opportunity to highlight on their platforms the welcoming attitude of the host community and to cover the settlement journeys of the newly arrived refugees. The coverage was not limited to traditional media outlets; the topic also received extensive local and international attention online and on emerging social media platforms.

This paper focuses on exploring the influence of media coverage and public opinion on the settlement and integration outcomes of resettled Syrian refugees in Canada. This paper will argue that positive online media coverage of Syrian refugees arriving in Canada, and the welcoming culture of Canadian society, have both influenced better settlement and integration outcomes for many Syrian refugees. It will also provide a better understanding of Canada's response to the Syrian refugee crisis and show how the process of resettlement becomes stronger when local community members and citizens are involved. I will demonstrate these arguments firstly by analyzing the relationship between welcoming cultures, positive media coverage, and the perception of refugees. Secondly, I will examine the role of media coverage in influencing welcoming cultures in Cana$\mathrm{da}$, as well as its role in encouraging community members and ordinary citizens to become involved in national humanitarian projects. Finally, information related to Canada's welcoming culture and positive media coverage are discussed relative to settlement outcomes, which portrays the strong influence of storytelling and inclusive communities on the success of new immigrants as they rebuild their lives in a new country. I will also outline the various refugee resettlement programs in Canada. A diverse range of academic research was used and analyzed to understand if there is a connection between public opinion, media coverage, and the public perception of refugees. In order to provide specific context and examples on the topic, two widely circulated and high-profile refugee stories were examined to explore the influence of media and public opinion on refugees. Additionally, a range of reports and studies by the Canadian government and international organizations like the UNHCR were analyzed to highlight the different refugee resettlement streams in Canada, and to examine the short and long term settlement and integration outcomes of each program.

3 J. Hyndman, W. Payne, S. Jimenez, Private refugee sponsorship in Canada, "Forced Migration Review", 54: 2017, pp. 56-59. 
There is a lot that can be learned from the response to the Syrian refugee crisis in Canada, lessons that may be valuable for similar future projects ${ }^{4,5}$. The role of media in the topic of migration is instrumental as it sets the agenda for public discourse, identifies opportunities and challenges, and may also provide solutions that lead to smooth and more successful integration of refugees in host countries 6 . According to Reker ${ }^{7}$, the term "Welcoming Culture" initially emerged in Germany in national conversations on demographic changes and refugees. It can be defined as a positive attitude of societies towards foreigners, and particularly towards refugees and immigrants. The appearance of a welcoming culture for refugees in the Canadian context can perhaps be dated back to the late 1970s with the launch of the private sponsorship program, and when a system was established by the government of Canada to engage the public in responding to the Indochina refugee crisis. The private refugee sponsorship program gave people the chance to take action by helping Indochinese refugees settle in Canada ${ }^{8}$. In 1986, the program won the United Nations Nansen Medal, the only time a whole country has ever been recognized with this refugee-focused award ${ }^{9}$. Since its inception, the private sponsorship program has allowed Canadians to offer a new home to more than 200,000 refugees ${ }^{10}$. Evidence suggests that the process of integration has proven to be more successful in the case of community involvement than for those admitted into the country through governmental assistance ${ }^{11}$. It is also important to note that private sponsorship

4 S. Marwah, Syrian refugees in Canada: Lessons learned and insights gained, "Ploughshares Monitor", 37 (2): 2016, pp. 9-11.

5 S. Pathberiya, Paying it forward: Lessons Learned from Syrian resettlement can prepare us for the future waves of climate change refugees, "Alternatives Journal”, 42 (3): 2016, pp. 62-66.

6 H. G. Boomgaarden, J. Matthes, S. Lecheler, Refugees, media, and public opinion: Theoretical and empirical perspectives, "Mass Communication and Society", 21 (4): 2018, pp. 531-532.

7 J. Reker, Welcoming Culture: The Benefits of Diversity, "Goethe Institute", October 2014: https://www.goethe.de/en/kul/ges/20439862.html.

8 B. Treviranus, M. Casasola, Canada's Private Sponsorship of Refugees Program: A Practitioners Perspective of its Past and Future, "Journal of International Migration and Integration", 4 (2): 2003, p. 184.

9 M. J. Molloy, J. C. Simeon, The Indochinese refugee movement and the launch of Canada's private sponsorship program, "Refuge: Canada's Journal on Refugees", 32 (2): 2016, p. 4.

10 J. Hyndman, W. Payne, S. Jimenez, op. cit., p. 56.

11 P. T. Lenard, Resettling Refugees: Is Private Sponsorship a Just Way Forward?, "Journal of Global Ethics", 12 (3): 2016, p. 302. 
came in as an addition to government assisted resettlement commitments, and not as a substitute ${ }^{12}$. In other words, the private sponsorship program arose out of the desire to do more for refugees ${ }^{13}$. This demonstrates the historical background behind the role of community members in influencing welcoming cultures for refugees in Canada.

\section{Relationship between media coverage and perception of refugees}

To argue that positive online media coverage has had an impact on $\mathrm{Ca}$ nada's response to the refugee crisis, it is important to prove first that there is a strong relationship between media and the perception of refugees. According to Danilova ${ }^{14}$, in the age of globalization, media have become a very powerful tool and some of the main determinants of public opinion. Media, and particularly online media have the ability to raise awareness about the daily experiences and challenges faced by refugees. More importantly, media coverage can influence the framework of immigration policy debates and the decision-making process ${ }^{15,16}$. Lawlor and Tolley ${ }^{17}$ affirm that there is a very strong relationship between media coverage and the perception of refugees. Their research (2017:968) states that media can either lead or follow public opinion, and that it holds the ability to shape policy responses towards refugees and migrants. A strong example of the relationship between media coverage and the perception of refugees can be observed through the story of Alan Kurdi, a three-yearold Syrian boy who drowned in the Aegean Sea in September 2015. The pho-

12 J. Hyndman, W. Payne, S. Jimenez, op. cit., p. 59.

13 S. Labman, Private Sponsorship: Complementary or Conflicting Interests?, "Refuge: Canada's Journal on Refugees", 32 (2): 2016, p. 76.

14 V. Danilova, Media and Their Role in Shaping Public Attitudes towards Migrants, "Our World", July 16 2014, https://ourworld.unu.edu/en/media-and-their-role-in-shaping-public-attitudes-towards-migrants.

15 D. G. Papademetriou, A. Heuser, Public Opinion, Media Coverage, and Migration: Developing Strategies for Immigration and Integration Reforms, "Migration Policy Institute", p. 4, May 2009: https://www.migrationpolicy.org/research/public-opinion-media-coverage-and-migrationdeveloping-strategies-immigration-and.

16 H. Dempster, K. Hargrave, Understanding public attitudes towards refugees and migrants, “Overseas Development Institute (ODI)", Working Paper 512: 2017.

17 A. Lawlor, E. Tolley, Deciding Who's Legitimate: News Media Framing of Immigrants and Refugees, "International Journal of Communication", 11: 2017, pp. 967-991. 
tos of Alan Kurdi triggered strong international reactions from governments, NGOs, citizens and politicians ${ }^{18}$. In fact, the Canadian response to the Syrian refugee crisis was arguably mainly fueled by this incident. The influence that Alan Kurdi's photo had was crucial in creating the Canadian public impression towards Syrian refugees ${ }^{19}$. The media coverage of this incident was a major contributor to the government's response and to mobilizing citizens. Tyyska, Blower, Deboer, Kawai and Walcott ${ }^{20}$ also found that media coverage plays an essential role in the construction of socially shared understandings and influential representations of newcomers, especially refugees.

That said, it is important to note that the existing relationship between media and the public perception of refugees is still a very sensitive topic given that it can be steered in directions that will not necessarily be in the best interests of vulnerable refugees. Kosho ${ }^{21}$ indicates that various studies on media coverage and public opinion concerning refugees have shown that the images in the media, the descriptions, and the labeling of the immigrants and refugees can influence public attitudes concerning immigrants, and impact the national policies on immigration. Media coverage holds a certain type of power over public opinion, and citizen should be aware and critical about the type of information they receive, or even seek. As framed by Boomgaarden, Matthes and Lechele ${ }^{22}$, the refugee crisis has shown how central digital and social media communication has become a part of many citizens' lives, with online social media platforms like Facebook and Twitter acting as first sources of information, as well as potential risks for political radicalization.

18 C. Bozdag, K. Smets, Understanding the Images of Alan Kurdi with "Small Data": A Qualitative, Comparative Analysis of Tweets about Refugees in Turkey and Flanders, "International Journal of Communication (Online)", 11: 2017, pp. 4046-4069.

19 V. Tyyska, J. Blower, S. Deboer, S. Kawai, A. Walcott, Canadian Media coverage of the Syrian Refugee Crisis: Representation, Response, and Resettlement, "Geopolitics, History, and International Relations", 10 (1): 2018, pp. 148-166.

20 Ibid.

21 J. Kosho, Media Influence on Public Opinion Attitudes Toward the Migration Crisis, "International Journal of Scientific \& Technology Research", 4 (8): 2015, p. 90.

22 H. G. Boomgaarden, J. Matthes, S. Lecheler, op. cit., pp. 531-532. 


\section{Positive coverage of Syrian refugees in Canadian media and welcoming attitudes of Canadian communities}

Canada's response to the Syrian refugee crisis in late 2015 can be considered unique and inspiring at a time when most Western countries were closing their doors to refugees. Positive online media coverage majorly contributed to the development of this national response. Portraying Syrian refugees positively through online platforms of Canadian media and institutions encouraged private sponsors across various communities in Canada to take action and support the newly arrived refugees ${ }^{23}$, unlike other countries, where negative coverage resulted in lower support for Syrian refugees. In fact, a 2018 report by the Environics Institute for Survey Research showed that one out of three Canadians had a connection with the Private Sponsorship of Refugees (PSR), either directly or through someone they knew ${ }^{24}$. The PSR is a program that allows Canadian Citizens and Permanent Residents to take part in the resettlement process by offering protection and helping refugees build a new life.

The Canadian online media coverage that focused on the public's volunteerism in relation to refugee resettlement is noteworthy ${ }^{25}$. Videos produced by organizations like UNHCR Canada and World Vision Canada were shared on social media platforms and gained thousands of viewers ${ }^{26,27}$. These videos focused on the welcoming attitudes presented by Canadian communities and citizens, and further enhanced the relationship between refugees and the newest community members. Swain reminds us that social media can both inform and misinform the public, and make significant changes in people's perceptions. The media had a positive impact on people's understanding of different cultures and struggles ${ }^{28}$. This is something we can observe in the Canadian context,

23 V. Tyyska, J. Blower, S. Deboer, S. Kawai, A. Walcott, op. cit., pp. 148-166.

24 Environics Institute for Survey Research, Canada's World Survey 2018. Final Report, 2018 pp. 1-35, https://www.environicsinstitute.org/docs/default-source/canada's-world-2018-survey/ canada's-world-survey-2018---final-report.pdf?sfvrsn=17208306_2.

25 V. Tyyska, J. Blower, S. Deboer, S. Kawai, A. Walcott, op. cit., pp. 148-166.

26 World Vision Canada. Canadian Children Welcome Syrian Refugees to Canada, 2015.

27 UNHCR. The Canadian Businessmen Who Sponsored Over 200 Syrian Refugees, 2017, https:/www.unhcr.ca/news/canadian-entrepreneur-invests-millions-syrian-refugees/.

28 L. Swain, The Influence of the Media on Public Perspective of the Syrian Refugee Crisis, "Concrete", October 6 2015, https://www.concrete-online.co.uk/the-influence-of-the-media-onpublic-perspective-of-the-syrian-refugee-crisis/. 
where many Canadian citizens had first-hand contact with Syrian refugees through the PSR program or by volunteering. Shedding light on these positive relationships through online content shaped the perception of the public and encouraged further community responses. Coker ${ }^{29}$ states that the media attention on the lived experiences of Syrian refugees moved Canadians to respond. An example of that can be seen through the actions of ordinary citizens who came together through online groups such as GTA Refugee Assistance Hub, a growing Facebook group with more than 3500 members, to support the newly arrived refugees by donating items and sharing resources ${ }^{30}$. It is arguable that online media platforms, whether through social media websites or online news coverage, have been instrumental in creating, or perhaps improving, welcoming attitudes towards Syrian refugees and by Canadian communities.

\section{Impact of positive online media coverage and welcoming cultures on the settlement and integration of refugees}

The online coverage of Syrian refugees in Canada has influenced welcoming attitudes among diverse populations in Canadian society. Based on that finding, it is safe to argue that the welcoming attitudes by the current government, organizations and ordinary citizens have contributed to successful settlement and integration outcomes for refugees. According to Tyyska, Blower, Deboer, Kawai and Walcott ${ }^{31}$, the acceptance and integration of Syrian refugees was mainly dependent on the way certain media platforms related the resettlement plan to the Canadian public. UNHCR Canada's 2017 data also showed that after less than one year, $90 \%$ of Syrian refugees resettled between 2015 and 2016 reported having a strong or very strong sense of belonging to Cana$\mathrm{da}^{32}$. Welcoming cultures can allow citizens to contribute more and refugees to integrate better. A good example of that is the story of Danby CEO Jim Estill, a Canadian citizen who was recognized as a global hero for his humanitarian actions in response to the refugee crisis. Estill contributed 1.5 million dollars to

29 C. Bolu, A Half Welcome, "Citizens for Public Justice”, 2017.

30 GTA Refugee Assistance Hub, https:/www.facebook.com/groups/973720629340291/.

31 V. Tyyska, Syrian Refugee Crisis in Canadian Media, "Ryerson Centre for Immigration and Settlement", 2017.

32 UNHCR Canada. Canadian Resettlement Fact Sheet, 2017. 
sponsor 58 Syrian refugee families - more than 200 people - and helped them settle and integrate in his hometown, Guelph Ontario, by providing language training, job opportunities and even helping some start their own business ${ }^{33}$. He took the lead and engaged over 800 volunteers to support this humanitarian initiative. Estill's story is one out of many stories that demonstrate the strength of welcoming cultures and communities. The story was circulated widely on social media platforms and perhaps encouraged new community members to take action and help.

Another positive impact that the online coverage created can be witnessed in the settlement and integration of refugees and their communities, where the successful settlement of one family or individual can form public opinion and also help fellow refugees find or navigate new opportunities. The Hadhad family are a good example on that. The Hadhad family landed in the town of Antigonish in Nova Scotia with the arrival of 25,000 Syrian refugees back in 2015. With the support of their new community, the family was able to rebuild their chocolate business that was bombed in their home country ${ }^{34}$. They called the business "Peace by Chocolate", and have been utilizing the power of social media platforms to promote their story and business. The story went viral online after it was mentioned by Canada's prime minister at the Leaders' Summit on Refugees at the UN in New York ${ }^{35}$. Today, almost three years later, the Hadhad's are hiring an additional 25 local community members to meet demand $^{36}$. It is hard to imagine this success happening without a welcoming culture for refugees and positive media coverage supporting it.

33 A. Kassam, The Canadian Who Spent C\$1.5M to Rescue More Than 200 Syrian Refugees, “The Guardian”, January 6 2017, https://www.theguardian.com/world/2017/jan/06/jim-estill-syrian-refugees-canada-guelph-ontario.

34 C. Ray, Syrian Chocolate Company in Antigonish Set to Double in Size, "CBC", August 5 2018, https://www.cbc.ca/news/canada/nova-scotia/peace-by-chocolate-antigonish-companydoubling-in-size-1.4774576.

35 C. Martin, Tareq Hadhad on Building a Successful Business in Canada as a Refugee, "The Globe and Mail", February 12 2018: https:/www.theglobeandmail.com/report-on-business/careers/ tareq-hadhad-on-building-a-successful-business-in-canada-as-a-refugee/article37933851.

36 C. Ray, op. cit. 


\section{Canada's Refugee Resettlement Programs}

According to the evaluation division at the Ministry of Immigration, Refugees and Citizenship Canada (IRCC), resettled refugees can be admitted into the country via one of the following three resettlement programs ${ }^{37}$ : the first program is the GAR, otherwise known as Government-Assisted Refugees. Through this program, the refugees to be sponsored are usually referred by the United Nations High Commissioner for Refugees (UNHCR) or other designated referral agencies, and the Government of Canada provides them with initial resettlement services and supports them financially for up to one year. GARs are also eligible to receive resettlement services (i.e. reception at port of entry, temporary housing, assistance in finding permanent accommodation, basic orientation, links to settlement programming and federal and provincial programs) provided by special organizations that have signed a contribution agreement with the government in order to deliver these services. The second program is PSR, otherwise known as Privately Sponsored Refugees. Under this program, refugees are sponsored by permanent residents or Canadian citizens. Refugees under the PSR program are resettled under the same conditions as those under the GAR program, but the PSR program allows the private sponsors to be more involved (one on one) in the resettlement process and offer protection over and above what is provided directly by the government (i.e. principle of additionality). The third program is called BVOR, the Blended Visa Office-Referred. Under this program, refugees are referred by the UNHCR or other designated referral agencies and identified by Canadian visa officers for participation in the BVOR program based on specific criteria. BVOR refugees receive up to six months of financial support from the Government of Canada, and six months of financial support from their sponsors, plus start-up expenses. Private sponsors are responsible for supporting the BVOR refugees socially and emotionally during their first year of arrival.

One of the main differences between the three programs is the involvement of community members and citizens in the resettlement process. Private-

37 I. IRCC, Canada welcomes more privately sponsored refugees in 2018, "Canada.ca", last modified April 10 2019, https:/www.canada.ca/en/immigration-refugees-citizenship/corporate/ mandate/policies-operational-instructions-agreements/timely-protection-privately-sponsored-refugees.html. 
ly Sponsored Refugees and the Blended Visa Office-Referred benefit from that involvement. For the purpose of this research, a deeper study into the Private Sponsorship Program will be conducted in order to present how it is strengthened by the support of local Canadians.

\section{Benefits of Implementing the Private Sponsorship Program}

According to the Canadian Council for Refugees (CCR), the private sponsorship program holds a unique position and has strong advantages when it comes to refugee resettlement in Canada. The program is capable of enriching the lives of both refugees and Canadian community members. For Canadians, it is a chance to contribute directly, be a part of a refugee resettlement process, and impact the lives of people who are seeking security and stability. For refugees, it is a chance to connect with people who know the country, and who can guide them through the process of blending in. Refugees tend to rely on their sponsors to overcome the loneliness and the isolation that come from the experience of being a refugee ${ }^{38}$. The CCR also argues that private sponsorship does not rely solely on public resources, but instead collects support and funds from faith and ethnic groups, families, and other community organizations. The support offered through the program is the equivalent of approximately \$79 million annually, as well as an estimated volunteer contribution of over 1,600 hours per refugee family ${ }^{39}$.

Jennifer Bond, chair of the Global Refugee Sponsorship Initiative and a professor at the University of Ottawa, talks about the benefits of the private sponsorship program by stating in a media interview that "The provision for private citizens to offer help not only provides a vehicle for tapping into communities, but also allows for individual Canadians to feel and be engaged." One of the strongest pillars of this program is its community engagement component, since it facilitates and creates opportunities for a deeper cultural understanding among both refugees and sponsors. The close relationship that is built up during the one-year sponsorship period tends to create bonds that go

39 Canadian Council for Refugees (CCR), The Private Sponsorship of Refugees Program: Current Challenges and Opportunities, April 2006, p. 2, http://ccrweb.ca/en/private-sponsorshiprefugees-program-current-challenges-and-opportunities. 
beyond the obligation, and soon become life-long friendships. Refugees have also reported a high level of satisfaction with their transitional experiences ${ }^{40}$. Krivenko also states that the private sponsorship of refugees is a key agenda for successful integration through the following:

No institution, including government, is able to create personal and lasting links between the refugees and the local community. The private sponsorship program naturally creates these links. It is imperative that any integration policy, and any program, draws on lessons drawn from the PSR and creates mechanisms that allow refugees to establish personal ties with the host community. Multiple forms of public-private partnership are conceivable in this context ${ }^{41}$.

In interviews conducted by the Global Refugee Sponsorship Initiative ${ }^{42}$, sponsors and refugees shared how the overall sponsorship process has strengthened their relationship and allowed them to understand each other's differences in culture and habits. These community relationships have also given these sponsors a way to understand firsthand what the real struggles and challenges are that these refugees have faced prior to their arrival Canada, and this has created public awareness and stimulated compassion towards strangers from other parts of the world. Another advantage of applying the private sponsorship model is that it gives the government fewer financial obligations to fulfill the needs of refugees during their first year, given that the sponsors are the ones who raise the funds to cover the expenses of the refugees, while the government mainly focuses on administering the program ${ }^{43}$.

40 P. T. Lenard, op. cit., p. 302.

41 E. Y. Krivenko, The Private Sponsorship of Refugees: A Key Agenda for Integration, "Policy Options", 5: 2016, p. 1.

42 Global Refugee Sponsorship Initiative, 2017, http://refugeesponsorship.org.

43 J. Kumin, Welcoming Engagement: How Private Sponsorship can Strengthen Refugee Resettlement in the European Union, Migration Policy Institute, 2015, p. 2-15: https://www.migrationpolicy.org/research/welcoming-engagement-how-private-sponsorship-can-strengthen-refugeeresettlement-european. 


\section{Role of Community in Resettlement}

Treviranus and Casasola ${ }^{44}$ state that the strength of sponsors and community members lies in their capacity to dedicate financial resources and time, knowledge in their community, and network as well as personal support. That said, the role of the community in successful refugee integration through the private sponsorship model is also demonstrated by the government's announcement to increase the level planned to four times the average number welcomed in the last 10 years, 2015 and prior ${ }^{45}$.

In a country like Canada, where immigration is considered to be an essential part of its formation, it is no surprise that communities and citizens are able to relate well to the journeys of refugees and migrants, and to respond to them accordingly. With the arrival of Syrian refugees in late 2015, the response of community members was remarkable, and triggered memories of that of the Indochinese influx (Boat People) back in the $1970 \mathrm{~s}^{46}$. We have also observed how Vietnamese refugees who experienced the same Canadian welcoming spirit have wanted to give back years later and help Syrian refugees integrate and thrive ${ }^{47,48}$. We notice that the involvement of active community members and volunteers can in fact strengthen and improve the overall process of refugee resettlement. Such collaborative actions can have various advantages and benefits to both the ones providing the help and for those receiving it.

\section{Conclusion}

The impact that positive online media coverage has had on the Canadian response to the Syrian refugee crisis from 2015-2018 is evident, and it has undoubtedly resulted in successful settlement and integration outcomes for many

44 B. Treviranus, M. Casasola, op. cit., p. 196.

45 I. IRCC, op. cit.

46 M. Friscolanti, How a Vietnamese boat person helped save a family of Syrian refugees, "Macleans", January 21, 2016, http://www.macleans.ca/news/canada/how-a-vietnamese-boat-person-helped-save-a-family-of-syrian-refugees/.

47 T. Carman, Two Generations of Boat People, 40 Years Apart; Refugees Who Fled Vietnam Band Together to Help Syrians, “The Vancouver Sun”, September 192015.

48 C. Szklarski, Vietnamese 'Boat People' Unite to Sponsor Syrians: 'it's the Least we can do', "The Canadian Press", December 9 2015: https://toronto.citynews.ca/2015/12/09/vietnamese-boatpeople-unite-to-sponsor-syrians-its-the-least-we-can-do/. 
Syrian refugees. The welcoming culture of Canadian society was critical during this process as it strengthened the country's collective community bonds and brought people from different backgrounds together for a shared national purpose. Our modern and emerging social media platforms, digital storytelling tools and interactive websites have played an essential role in making all these group efforts possible.

The private refugee sponsorship model in Canada was examined to show how government and citizens can work together to achieve better humanitarian, social and economic results. We have seen how the involvement of citizens and community members in the settlement process can bring about positive results to the lives of refugees as they walk their first steps in a new country. The impact is much greater than finding employment, assisting in health-related issues, social support, or cultural integration. The impact is seen and felt in the friendships and community connections that are built among local citizens and refugees throughout the entire sponsorship process and beyond. This, however, does not mean that other refugee resettlement programs are not effective or helpful. It demonstrates that there is an opportunity to build on success and community connections through storytelling and positive media coverage to encourage citizens to take action and create a more welcoming environment for refugees and future citizens.

Moreover, the Canadian response to the Syrian refugee crisis has demonstrated to the world a different approach to civic engagement and humanitarian work. This national humanitarian response may be perceived as a major successful project. However, it also leaves us with many unanswered questions around the topic, and most importantly, questions about the relationship between politics and power, citizenship, culture, online media and public opinions. 


\section{References}

Boomgaarden, H. G., Matthes J., \& Lecheler S. (2018). Refugees, Media, and Public Opinion: Theoretical and Empirical Perspectives. Mass Communication and Society, 21(4), 531-532.

Bozdag, C., \& Smets K. (2017). Understanding the Images of Alan Kurdi with "Small Data": A

Qualitative, Comparative Analysis of Tweets about Refugees in Turkey and Flanders. International Journal of Communication (Online), 11, 4046-4069.

Canadian Council for Refugees (CCR) (2006, April). The Private Sponsorship of Refugees Program: Current Challenges and Opportunities. http://ccrweb.ca/en/ private-sponsorship-refugees-program-current-challenges-and-opportunities

Carman, T. (2015, September 19). Two Generations of Boat People, 40 Years Apart; Refugees Who Fled Vietnam Band Together to Help Syrians. The Vancouver Sun. Bolu, C. (2017). A Half Welcome. Citizens for Public Justice 2017.

Danilova, V. (2014, July 16). Media and Their Role in Shaping Public Attitudes towards Migrants. Our World. https://ourworld.unu.edu/en/media-and-their-role-inshaping-public-attitudes-towards-migrants

Dempster, H., \& Hargrave, K. (2017). Understanding public attitudes towards refugees and migrants. Overseas Development Institute (ODI), Working Paper 512.

Environics Institute for Survey Research (2018). Canada's World Survey 2018. Final Report (pp. 1-35). https://www.environicsinstitute.org/docs/default-source/ canada's-world-2018-survey/canada's-world-survey-2018---final-report.pdf?sfvrsn=17208306_2

Friscolanti, M. (2016, January 21). How a Vietnamese boat person helped save a family of Syrian refugees. Macleans. http://www.macleans.ca/news/canada/ how-a-vietnamese-boat-person-helped-save-a-family-of-syrian-refugees/

Global Refugee Sponsorship Initiative (2017). http://refugeesponsorship.org Hyndman, J., Payne W., \& Jimenez S. (2017). Private Refugee Sponsorship in Canada. Forced Migration Review, 54, 56-59.

IRCC, I. Canada welcomes more privately sponsored refugees in 2018. Canada. ca. (last modified April 10 2019). https://www.canada.ca/en/immigration-refugees-citizenship/corporate/mandate/policies-operational-instructions-agreements/ timely-protection-privately-sponsored-refugees.html 
Krivenko, E. Y. (2016). The Private Sponsorship of Refugees: A Key Agenda for Integration. Policy Options, 5, 1.

Kumin, J. (2015). Welcoming Engagement: How Private Sponsorship Can Strengthen Refugee

Resettlement in the European Union. Migration Policy Institute, 2-15. https://www. migrationpolicy.org/research/welcoming-engagement-how-private-sponsorshipcan-strengthen-refugee-resettlement-european

Kassam, A. (2017, January 6). The Canadian Who Spent C\$1.5M to Rescue More Than 200 Syrian Refugees. The Guardian. https://www.theguardian.com/world/2017/jan/06/jim-estill-syrian-refugees-canada-guelph-ontario

Kosho, J. (2015). Media Influence on Public Opinion Attitudes Toward the Migration Crisis.

International Journal of Scientific \& Technology Research, 4(8), 86-91.

Labman, S. (2016). Private Sponsorship: Complementary or Conflicting Interests? Refuge: Canada's Journal on Refugees, 32(2), 67-80.

Lawlor, A., \& Tolley, E. (2017). Deciding Who's Legitimate: News Media Framing of Immigrants and Refugees. International Journal of Communication, 11, 967991.

Lenard, P. T. (2016). Resettling Refugees: Is Private Sponsorship a just Way Forward?, Journal of Global Ethics, 12(3), 300-310.

Levitz, S. (2016, March 31). A Timeline of Canada's Policies and Decisions during the Syrian Refugee Crisis. The Canadian Press. https://toronto.citynews. ca/2016/03/31/a-timeline-of-canadas-policies-and-decisions-during-the-syrianrefugee-crisis/

Martin, C. (2018, February 12). Tareq Hadhad on Building a Successful Business in Canada as a Refugee. The Globe and Mail. https://www.theglobeandmail.com/ report-on-business/careers/tareq-hadhad-on-building-a-successful-business-incanada-as-a-refugee/article37933851

Marwah, S. (2016). Syrian Refugees in Canada: Lessons Learned and Insights Gained. Ploughshares Monitor, 37(2), 9-11.

McMurdo, A. M. B. (2016). Causes and Consequences of Canada's Resettlement of Syrian Refugees. Forced Migration Review, 52, 82-84.

Molloy, M. J., \& Simeon, J. C. (2016). The Indochinese Refugee Movement and the Launch of Canada's Private Sponsorship Program. Refuge: Canada's Journal on Refugees, 32(2), 3-9. 
Papademetriou, D. G., \& Heuser, A. (2009, May). Public Opinion, Media Coverage, and Migration: Developing Strategies for Immigration and Integration Reforms. Migration Policy Institute. https://www.migrationpolicy.org/research/public-opinion-media-coverage-and-migration-developing-strategies-immigration-and

Pathberiya, S. (2016). Paying it Forward: Lessons Learned from Syrian Resettlement Can Prepare Us for the Future Waves of Climate Change Refugees. Alternatives Journal, 42(3), 62-66.

Ray, C. (2018, August 5). Syrian Chocolate Company in Antigonish Set to Double in Size. CBC. https://www.cbc.ca/news/canada/nova-scotia/peace-by-chocolateantigonish-company-doubling-in-size-1.4774576

Reker, J. (2014, October). Welcoming Culture: The Benefits of Diversity. Goethe Institute. https://www.goethe.de/en/kul/ges/20439862.html

Swain, L. (2015, October 6). The Influence of the Media On Public Perspective of the Syrian Refugee Crisis. Concrete. https://www.concrete-online.co.uk/the-influence-of-the-media-on-public-perspective-of-the-syrian-refugee-crisis/

Szklarski, C. (2015, December 9). Vietnamese 'Boat People' Unite to Sponsor Syrians: 'it's the Least we can do'. The Canadian Press. https://toronto.citynews. ca/2015/12/09/vietnamese-boat-people-unite-to-sponsor-syrians-its-the-leastwe-can-do/

Treviranus, B., \& Casasola, M. (2003). Canada's Private Sponsorship of Refugees Program: A Practitioners Perspective of its Past and Future. Journal of International Migration and Integration, 4(2), 177-202.

Tyyska, V., Blower, J., Deboer, S., Kawai, S., \& Walcott, A. (2018). Canadian Media coverage of the Syrian Refugee Crisis: Representation, Response, and Resettlement. Geopolitics, History, and International Relations, 10(1), 148-166.

Tyyska, V. (2017). Syrian Refugee Crisis in Canadian Media. Ryerson Centre for Immigration and Settlement.

UNHCR Canada (2017). Canadian Resettlement Fact Sheet.

UNHCR (2017). The Canadian Businessmen Who Sponsored Over 200 Syrian Refugees. https://www.unhcr.ca/news/canadian-entrepreneur-invests-millions-syrianrefugees/

World Vision Canada (2015). Canadian Children Welcome Syrian Refugees to Canada.

GTA Refugee Assistance Hub. https://www.facebook.com/groups/97372062934 0291/ 